\title{
Mewujudkan Kemandirian Pangan melalui Pemanfaatan Pekarangan Rumah Singgah di Desa Galiran Kabupaten Klungkung Bali
}

\author{
Purwaningtyas Kusumaningsih $^{1}$, Diah Widiawati Retnoningtyas ${ }^{2}$, I Gede Mustika ${ }^{3}$ \\ Universitas Dhyana Pura, Jln. Raya Padangluwih, Dalung, Kuta Utara, Dalung, Kec. Kuta Utara, \\ Kabupaten Badung, Bali 80361 ${ }^{12,3}$ \\ Email: purwak.05@undhirabali.ac.id ${ }^{1}$
}

\begin{abstract}
ABSTRAK
Salah satu peran serta masyarakat dalam mendukung program pemerintah dalam ketahanan pangan adalah memanfaatkan sumber daya alam lokal. Setiap daerah memiliki sumber daya alam berbeda-beda yang dapat digunakan sebagai pemenuhan kebutuhan pangan seperti tanaman keladi, singkong, pepaya, pisang, mangga, kangkung, dan cabai. Pemanfaatan lahan kosong disekitar lingkungan tempat tinggal dapat digunakan untuk menanam dan mengembangkan beberapa jenis tanaman tersebut. Sehingga pemenuhan gizi dari pangan akan dengan mudah terpenuhi. Pengabdian dilakukan pada tanggal 14-15 September 2019, yang berlokasi di Rumah Singgah, Desa Galiran, Kabupaten Klungkung, Bali. Tujuan dari pengabdian ini adalah menanamkan pemahaman tentang kemandirian pangan dan bagaimana mewujudkannya. Serta keuntungan bagi mereka sebagai sumber kecukupan pangan dan gizi sehari-hari. Metode yang digunakan dalam pengabdian ini tim pengabdi memberikan penyuluhan tentang pengetahuan kemandirian pangan hubungannya dengan ketersediaan pangan. Pemanfaatan lahan kosong menjadi lahan produktif untuk ditanami tanaman buahbuahan, sayuran dan keladi sebagai sumber pangan pokok, vitamin dan dapat mengurangi pengeluaran. Sebelum dan sesudah penyuluhan peserta diberikan pre dan post-test yang hasilnya menunjukkan peningkatan pengetahuan peserta melalui analisis uji Wilcoxon sebesar $0,011<0,05$. Beberapa bibit tanaman diberikan sebagai stimulator kegiatan menanam yang hasilnya nanti dapat dinikmati bersama. Dampak dari pelaksanaan pengabdian ini mitra memperoleh ilmu pengetahuan tentang kemandirian pangan, serta aplikasinya dalam budidaya bibit tanaman. Salah satu dampak positif penanaman bibit pisang di pekarangan Rumah Singgah, sudah menghasilkan buah pisang.
\end{abstract}

Kata kunci: Bercocok Tanam, Gizi Cukup, Pangan.

\begin{abstract}
One of community participation to support government programs in resilience food, utilizes local natural resources. Each district has different types of natural resources, which use as a fulfillment of food needs, such as taros, cassavas, papayas, bananas, mangoes, kales, and chilies. The utilization of unused yards around the house can be utilized to plant and grow several types of plants. It will make it easier to fulfill food nutrition. This program was held on 14-15 September 2021 at Orphans House at Galiran village, Klungkung Bali. The aim of this program is to give knowledge about food resilience and the way to realize it. The advantages is will give them adequate of food and nutrition resource daily. The method that we used in this program was giving a lecture about the resilience of food which connected to food availability. Utilized unproductive yard to be productive by the planting of fruits, vegetables, and taro as a staple food, vitamin resource and will reduce the expenses. We have done pre and post-test before and after doing a lecture, the obtained result is $0,011<0,05$ which analyzed by Wilcoxon. The result showed if the knowledge of the participant has increased. Some of the plants' seeds have been given as a stimulator farming activity where they will enjoy the harvest. The positive impact to the orphans was they received knowledge about food resilience and the application by receiving plant seed. One of the greatest impacts that banana seeds which had planted, has been growing and given results.
\end{abstract}

Keywords: Adequate in Nutrition, Farming, Food. 


\section{PENDAHULUAN}

Pemenuhan kebutuhan pangan secara merata di masyarakat merupakan tujuan program pemerintah di ketahanan pangan. Akan tetapi keterlibatan masyarakat secara mandiri dalam penyediaan pangan juga diperlukan. Diantaranya pemanfaatan lahan kosong di pekarangan sekitar rumah dengan menanam tanaman yang dapat mencukupi kebutuhan sehari-hari seperti sayuran dan buah-buahan. Tanaman seperti keladi, singkong, dan ketela, selain dapat memberikan sumber karbohidrat, daunnya juga dapat dimanfaatkan sebagai sayuran. Apabila masyarakat aktif dalam memanfaatkan lahan pekarangan disekitar rumah dengan menanam sumber daya alam yang ada disekitar, kegiatan tersebut sudah termasuk dalam upaya kemandirian pangan (Sunarsih dkk., 2014); (Amruddin dan Iqbal, 2018); (Kastanja dkk., 2019).

Oleh karena itu pada pengabdian ini, penulis ingin menanamkan pentingnya peran serta masyarakat dalam mendukung program pemerintah. Khususnya dalam mewujudkan kemandirian pangan. Peran serta tersebut adalah dalam bentuk penyediaan pangan dengan memanfaatkan lahan sekitar. Pemahaman ini perlu ditanamkan kepada anak-anak hingga dewasa, sehingga mereka mengerti tentang ketahanan dan kemandirian pangan. Mampu mewujudkannya dalam kehidupan sehari-hari dan mendatangkan manfaat bagi mereka.

Rumah Singgah dipilih menjadi mitra disebabkan sesuai dengan tujuan pengabdian. Rumah Singgah merupakan rumah penampungan anak-anak yatim piatu yang sangat memerlukan perhatian. Perhatian yang dapat kita berikan berupa peningkatan pengetahuan. Salah satunya yang berkaitan dengan kebutuhan mereka yaitu dalam hal peningkatan kesejahteraan. Kesejahteraan akan meningkat apabila mereka bisa memahami cara memenuhi kebutuhan pangan sehari-hari. Ketersediaan pangan tentunya akan menjamin asupan gizi bagi anak-anak. Gizi yang baik tentunya akan mendukung kesehatan, perkembangan otak, jasmani dan aktivitas di sekolah, di rumah ataupun kegiatan ekstra lainnya. Hasil observasi memperlihatkan masih ada lahan disekitar Rumah Singgah Budi Suci Dana yang berlokasi di Desa Galiran, Kabupaten Klungkung yang belum dimaksimalkan penggunaannya. Lahan akan lebih baik apabila tidak dibiarkan kosong atau hanya ditanami oleh satu atau dua jenis tanaman buah saja. Apabila ditanami lebih beragam buah, kedepannya akan tersedia berbagai pilihan buah bervitamin yang baik bagi anak-anak asuh beserta penghuni lainnya. 


\section{METODE}

Pengabdian ini menggunakan metode Asset Based Community Development (ABCD) dengan penyuluhan tentang pemahaman ketahanan dan kemandirian pangan serta manfaatnya. Penyuluhan diberikan kepada penghuni Rumah Singgah Budi Suci Dana di Desa Galiran, Klungkung Bali. Sebelum dan sesudah penyuluhan, para peserta diberikan pre dan post-test untuk mengetahui apakah dengan pemberian materi penyuluhan terjadi perubahan pengetahuan di peserta. Analisis data yang digunakan uji Wilcoxon Match Paired Test dengan SPSS 16. Tim pengabdi menyerahkan bibit tanaman kepada pengurus Rumah Singgah Budi Suci Dana di akhir kegiatan pengabdian (Mardiyanto dan Parastuti, 2016); (Fauziah, 2020). Pengabdian telah dilaksanakan pada tanggal 14-15 September 2019, mengambil lokasi di Rumah Singgah Budi Suci Dana, Desa Galiran, Klungkung Bali sebagai mitra. Pelaksanaan pengabdian ini melibatkan 2 orang mahasiswa Program Studi Gizi Universitas Dhyana Pura, Bali dalam sosialisasi pengabdian.

\section{HASIL, PEMBAHASAN, DAN DAMPAK}

Pelaksanaan pengabdian dimulai dengan sosialisasi kepada mitra, untuk menjelaskan maksud dan tujuan pengabdian serta jadwal pelaksanaan pengabdian. Sosialisasi diberikan oleh mahasiswa kepada para peserta yaitu penghuni Rumah Singgah Budi Suci Dana. Para peserta berjumlah 13 orang secara keseluruhan terdiri dari anak-anak asuh dan pengasuh. Karakterisasi peserta berdasarkan pendidikan dapat dilihat pada Tabel. 1. Oleh karena tingkat pendidikan yang seragam dari anak-anak asuh yaitu SD, SMP dan SMA serta lulusan pendidikan pengasuh, maka tim pengabdi memberikan materi secara umum yang dapat dengan mudah dimengerti oleh berbagai latar belakang pendidikan.

Tabel 1. Latar belakang pendidikan peserta pengabdian

\begin{tabular}{cc}
\hline Tingkat Pendidikan & Jumlah \\
\hline SD & 2 \\
SMP & 4 \\
SMA & 7 \\
Total & 13 \\
\hline \hline
\end{tabular}

Materi yang diberikan berupa pengertian tentang ketersediaan pangan sebagai pemenuhan pangan dan gizi keluarga (Solihin dkk., 2018) (Sukenti dkk., 2019). Kecukupan pangan untuk kebutuhan sehari-hari dengan memanfaatkan lahan kosong disekitar rumah singgah. Kegiatan tersebut akan dapat memenuhi kecukupan gizi anak-anak asuh (Kurnia dkk., 2020). Tercukupinya gizi pada anak-anak asuh, maka akan meningkatkan 
produktivitas anak-anak dalam menuntut ilmu, dapat mencegah kekurangan gizi dan mengajarkan anak-anak keterampilan bercocok tanam. Apabila dilihat dari segi ekonomi, akan sangat membantu, dimana dapat menghemat biaya pembelian buah dan sayuran (Ashari dkk., 2016); (Ratna dan Gustiani, 2016); (Osa dan Temu, 2020). Penghematan tersebut dapat digunakan untuk pembelian non pangan seperti kesehatan, pendidikan, MCK (pasta gigi, sabun, sikat gigi, dan lain-lain.) dan pakaian (Mulyo dkk., 2016). Pemberian pre dan post-test dilaksanakan sebelum dan sesudah penyuluhan kepada peserta. Hasil yang ditunjukkan terjadi perubahan pengetahuan tentang kemandirian pangan, dilihat dari peningkatan nilai $p$-value nilai tes sesudah pemberian ceramah. Perubahan ini ditunjukkan dengan nilai symptotic significance $0,011<0,05(\mathrm{p}<0,05)$ dapat dilihat pada tabel 2 . menggunakan uji Wilcoxon. Hasil kegiatan pengabdian menjelaskan bahwa peserta mampu memahami materi yang diberikan dengan baik. Umpan balik dari peserta yang sebagian sedang menempuh pendidikan, mereka berpendapat kegiatan ini menambah ilmu pengetahuan mereka. Mereka semakin mengerti, bercocok tanam dapat dijadikan kegiatan bermanfaat disela-sela waktu sepulang sekolah.

Tabel 2. Uji Wilcoxon

\begin{tabular}{llrrr}
\hline & & $N$ & Mean Rank & Sum of Ranks \\
\hline Post test - Pre Test & Negative Ranks & $0^{\mathrm{a}}$ & .00 & .00 \\
\cline { 2 - 5 } & Positive Ranks & $8^{\mathrm{b}}$ & 4.50 & 36.00 \\
\cline { 2 - 5 } & Ties & $5^{\mathrm{c}}$ & & \\
\cline { 2 - 5 } & Total & 13 & & \\
& & & & \\
\hline a. Post test < Pre Test & & & & \\
b. Post test $>$ Pre Test & & &
\end{tabular}

Test Statistics ${ }^{b}$

\begin{tabular}{lr}
\hline & \multicolumn{2}{c}{ Post test - Pre } \\
\hline$Z$ & $-2.536^{a}$ \\
\hline Asymp. Sig. (2-tailed) & .011 \\
\hline a. Based on negative ranks. & \\
b. Wilcoxon Signed Ranks Test &
\end{tabular}

Rumah Singgah Budi Suci Dana, sebelumnya pernah menerima beberapa pengabdian dari institusi lain seperti peningkatan sanitasi diri dan lingkungan. Pengabdian berupa upaya pemenuhan kebutuhan pangan dengan pemanfaatan lahan, belum pernah mitra terima. Kegiatan ini memberikan masukan salah satu cara partisipasi masyarakat, mendukung program pemerintah yaitu ketahanan pangan. Mitra, baru kali ini memperoleh penyuluhan tentang apa itu ketahanan pangan dan aplikasinya di masyarakat. Selain dapat memenuhi 
kebutuhan pangan sehari-hari, bisa mengurangi pengeluaran dan asupan gizi bagi anak-anak terjamin. Pelaksanaan terakhir dari pengabdian ini, diserahkan beberapa bibit tanaman sumber vitamin dan karbohidrat berupa 6 bibit pisang cavendis, 2 bibit mangga arumanis, 2 jambu kristal, 1 bibit rambutan dan 6 bibit keladi. Bibit tersebut sudah ditanam di lahan kosong disekitar Rumah Singgah dan sekitar kurang lebih 15 bulan berikutnya, bibit sudah menghasilkan yaitu pisang cavendis.
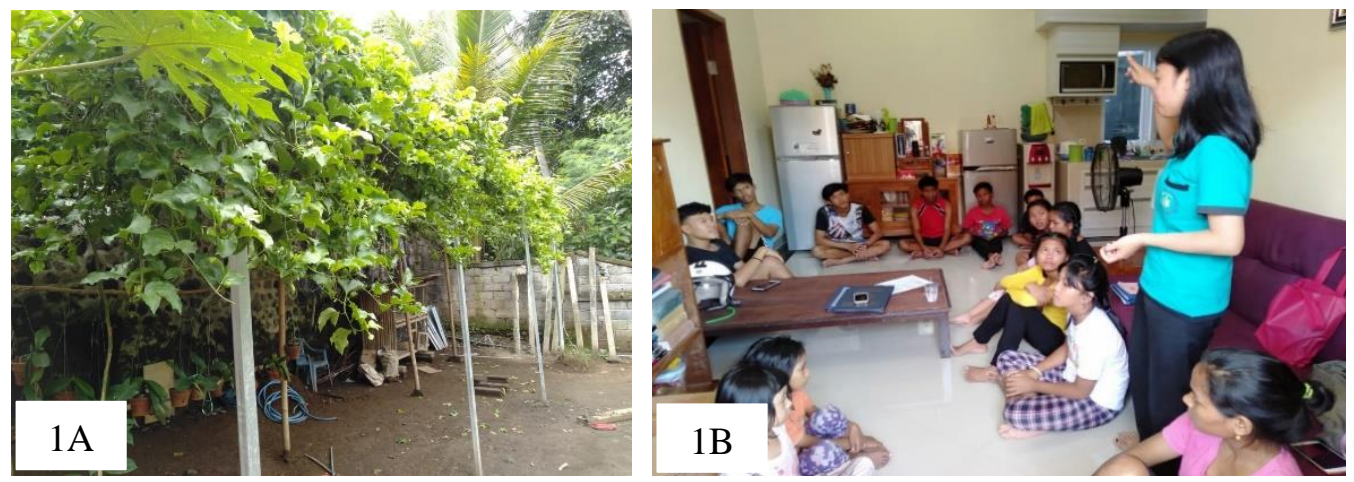

Gambar 1A. Observasi lahan kosong disekitar Rumah Singgah. 1B. Sosialisasi tentang pelaksanaan Pengabdian di Rumah Singgah oleh mahasiswa Gizi Undhira, Bali
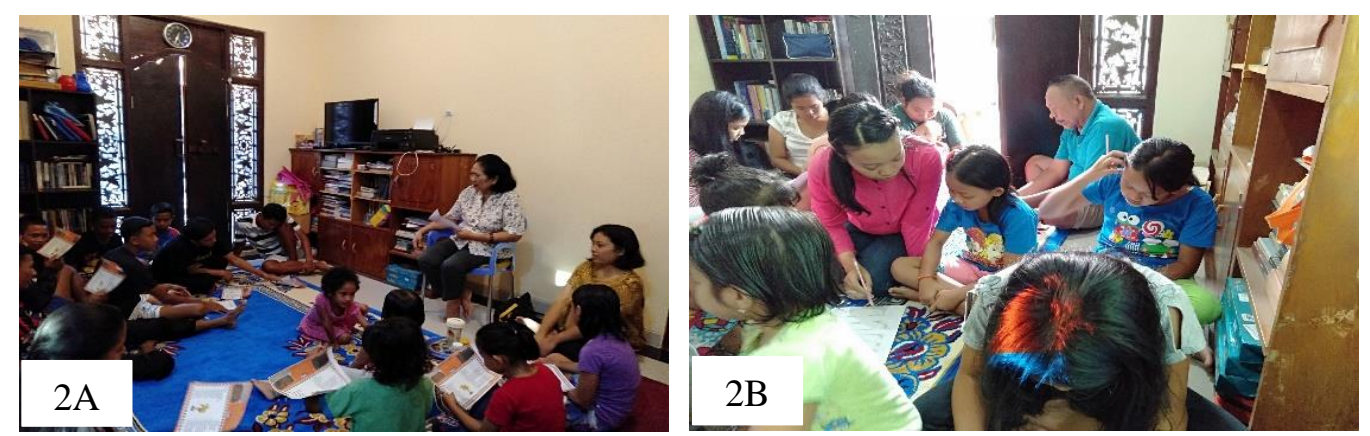

Gambar 2A. Penyuluhan kegiatan bercocok tanam dan pengetahuan kemandirian pangan kepada peserta pengabdian. 2B. Pelaksanaan dan pendampingan pre dan post-test peserta oleh mahasiswa Gizi, Undhira Bali
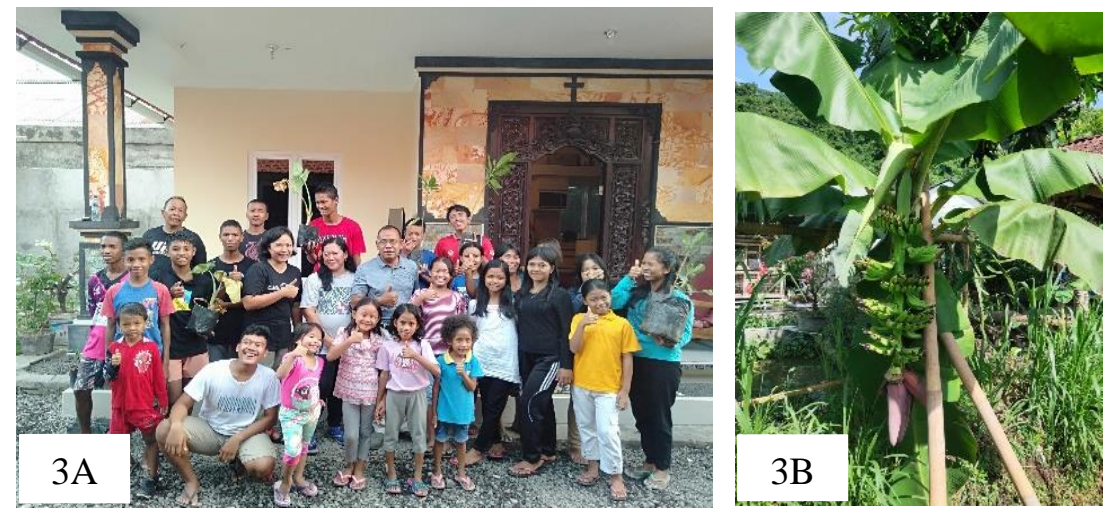

Gambar 3A. Penyerahan bibit tanaman dan foto bersama anak-anak asuh. 3B. Pisang cavendis yang ditanam di pekarangan Rumah Singgah sudah berbuah 


\section{SIMPULAN}

Pengabdian yang dilaksanakan berjalan dengan lancar, antusias para peserta sangat terlihat dari keseriusan mereka mendengarkan dan berdiskusi. Hal ini terlihat dari sesi tanya jawab dan hasil pre dan post-test yang menunjukkan peningkatan. Bibit tanaman yang diberikan diterima dengan senang hati oleh kepala Rumah Singgah, anak-anak asuh beserta pengasuh. Bibit ditanam di pekarangan sekitar Rumah Singgah dan ada yang sudah menghasilkan.

\section{UCAPAN TERIMAKASIH}

Penulis mengucapkan terima kasih kepada LPPM Universitas Dhyana Pura, Bali yang telah mendukung kegiatan Pengabdian ini sehingga dapat terlaksanakan dengan baik.

\section{DAFTAR PUSTAKA}

Amruddin, dan Iqbal, M. (2018). Pemanfaatan Lahan Pekarangan sebagai Upaya Pemenuhan Kebutuhan Keluarga di Desa Kanjilo Kecamatan Barombong Kabupaten Gowa. Jurnal Ziraa'ah, 43(1), 70-76. http://dx.doi.org/10.31602/zmip.v43i1.1073

Ashari, N., Saptana, N., dan Purwantini, T. B. (2016). Potensi dan Prospek Pemanfaatan Lahan Pekarangan untuk Mendukung Ketahanan Pangan. Forum Penelitian Agro Ekonomi, 30(1), 13-30. http://dx.doi.org/10.21082/fae.v30n1.2012.13-30

Fauziah, Z. (2020). Optimalisasi lahan pekarangan sebagai upaya pemenuhan kebutuhan pangan keluarga. Jurnal Pengabdian Kepada Masyarakat, 1(1), 28-34.

Kastanja, A. Y., Patty, Z., Dilago, Z., Kesehatan, S., dan Namotemo, U. H. (2019). Pemanfaatan Pekarangan Untuk Mendukung Ketahanan Pangan Masyarakat Desa Kali Upa. Jurnal Pengabdian Masyarakat: Darma Bakti Teuku Umar, 1(1), 173-181. https://doi.org/10.35308/baktiku.v1i1.1468

Kurnia, R., Yusuf, M. N., dan Andrie, B. M. (2020). Pelatihan Pemanfaatan Pekarangan sebagai Upaya Pemenuhan Gizi Keluarga di Kelompok Wanita Tani "Lingkung Gunung." ABDIMAS GALUH, 2(2), 135-142. http://dx.doi.org/10.25157/ag.v2i2.4009

Mardiyanto, T. C., dan Parastuti, T. R. (2016). Efektivitas Pelatihan Teknologi Budidaya Bawang Putih Varietas Lokal Ramah Lingkungan dengan Metode Ceramah di Kabupaten Karanganyar. Jurnal Agraris, 2(1), 61-68. https://doi.org/10.18196/agr.2126

Mulyo, J. H., Sugiyarto, S., dan Widada, A. W. (2016). Ketahanan Dan Kemandirian Pangan Rumah Tangga Tani Daerah Marginal Di Kabupaten Bojonegoro. Agro Ekonomi, 
26(2), 121-128. https://doi.org/10.22146/agroekonomi.17265

Osa, D. B., dan Temu, S. T. (2020). Pemenuhan Asupan Gizi Keluarga Dalam Rangka Penanganan Stunting Di Desa Laimeta Kecamatan Kambata Mapa Mbuhang Kabupaten Sumba Timur. Pengabdian Kepada Masyarakat LPPM Universitas Cendana, 14(2), 13-16.

Ratna, N., dan Gustiani, E. (2016). Kontribusi Pemanfaatan Lahan Pekarangan terhadap Pemenuhan Gizi Keluarga dan Pengeluaran Pangan Rumah Tangga. Prosiding Seminar Nasional Inovasi Teknologi Pertanian, 80, 1751-1756.

Solihin, E., Sandrawati, A., dan Kurniawan, W. (2018). Pemanfaatan Pekarangan Rumah untuk Budidaya Sayuran sebagai Penyedia Gizi Sehat Keluarga. Jurnal Pengabdian Kepada Masyarakat, 2(8), 1-2.

Sukenti, K., Rohyani, I. S., dan Jupri, A. (2019). Optimalisasi Pemanfaatan Lahan Pekarangan Sebagai Upaya dalam Membantu Ketersediaan Pangan dan Perekonomian Masyarakat di Desa Sukarema, Kabupaten Lombok Timur. Jurnal Pengabdian Magister Pendidikan IPA, 2(1), 97-101. https://doi.org/10.29303/jpmpi.v2i1.362

Sunarsih, Saptana, dan Friyatno, S. (2014). Kearifan lokal dalam pemanfaatan pekarangan untuk mendukung ketahanan pangan rumah tangga. Prosiding Seminar Nasional Hari Pangan Sedunia Ke-33: Optimalisasi Sumberdaya Lokal Melalui Diversifikasi Pangan Menuju Kemandirian Pangan Dan Perbaikan Gizi Masyarakat Menyongsong Masyarakat Ekonomi ASEAN 2015, 434-445. 